\title{
PROFESSIONAL READINESS OF ELEMENTARY SCHOOL TEACHERS IN ADDRESSING AND PREVENTING RISK BEHAVIOR ${ }^{1}$
}

\author{
Eva Urbanovská \\ Alena Petrová
}

\begin{abstract}
The paper focuses on the personality of a teacher and his role in the primary prevention of the risk behavior. The article presents the partial results of a questionnaire survey that has been carried out in 2017 with 302 teachers at 12 elementary schools and multi-annual high schools as a partial output of the project RRC/08/2016 Professional readiness of primary school teachers for the risk behavior and its prevention in the Moravian-Silesian Region. The aim of the questionnaire survey was to find out about the relevant facts on the current readiness of elementary school teachers for the risk behavior and its prevention from the point of view of the actual teachers. The questionnaire has been designed by the authors of this paper (consisting of 46 scalable items and 7 open items). Only data from scalable items are included in the paper. The majority of teachers are ready to cooperate with their colleagues and other professionals in the field of solution and prevention of the risk behavior. Most of them find the prevention activities beneficial, they incorporate them into their lessons. When looking for a solution to a given problem as well as when practicing prevention activities, the teachers make use of the discussion with students. Although the obtained results might be region-specific, the authors are of the opinion that these can be regarded as relevant and inspiring for the professional and teaching public.
\end{abstract}

\section{Keywords}

primary prevention, risk behavior, teacher, professional readiness, elementary school, questionnaire survey

\footnotetext{
1 This paper has been prepared within Project No. RRC/08/2016, Professional Readiness of Primary School Teachers for the Risk Behavior and Its Prevention in the Moravian-Silesian Region, which was supported within the subsidy on the Promotion of Research and Development in the Moravian-Silesian Region 2016.
} 


\section{Theoretical bases}

Pedagogical staff encounters behavior manifestations of some pupils and students that surprise them unpleasantly, or even throw them off guard, almost on an everyday basis. They often resolve the situations intuitively, according to their experience and the ability to improvise. The educational aspect is probably the most demanding part of the teacher's professional work in the entire school field. Behavioral disorders or even the occurrence of social pathology always have a multi-causal character. The teacher becomes a highly significant factor in the child's individual life journey within the socialization process, next to the dominant influence of the family and its main responsibility.

The teacher plays an important role in the process of primary prevention of students' risk behavior. A quality teacher with interest in the child, a positive school atmosphere, pedagogical staff and the class atmosphere are all essential for the fulfillment of objectives in this area. Teachers must have all the required competences. The relation between the teachers' social competences, or their approach strategies, and the occurrence of aggressive behavior of the students is documented, for example, in the study by Csémy et al. (2014). Unjust treatment from the teachers, the stressful character of the school, unpopularity of the school environment and excessive expectations of the teachers have shown to be significant predictors of the students' aggressive behavior. The study by Sádovská and Kusý (2019) demonstrated the negative effect of an insecure, dissatisfied, reproving and strict interaction style on the pro-social behavior of students. On the other hand, a positive effect was demonstrated in an organizing, understanding interaction that leads to responsibility. The relation between the teacher's behavior and the students' bad behavior in the class was studied by Lopes et al. (2017). All teachers participate in the resolution of risk behavior cases and its prevention. But how are they prepared for that? Many experts, both domestic and international, are currently seeking an answer to that question (e.g., Jedlička et al., 2015; Valenta, 2013; Vágnerová, 2014; Špatenková et al., 2017; Miovský et al., 2010; Kraus et al., 2001; Zimmermann, 2002; Werner, 1990; Haggerty \& Garmezy, 1996; Jennings et al., 2017; Rucinski, Brown, \& Downer, 2018 etc.), however, the scope of our work does not allow for a more detailed description of their contribution. The question of a teacher's readiness in the field of primary prevention and solution of risk behavior cases was examined in Research Project No. RRC/08/2016, Professional Readiness of Primary School Teachers for the Risk Behavior and Its Prevention in the Moravian-Silesian Region, which was supported within the subsidy on the Promotion of Research and Development in the Moravian-Silesian Region 2016. The project was implemented by a research team of the Institute of Pedagogical and Psychological Sciences at the Faculty of Public Policies of the Silesian University in 2016-2017. Its main objective was to determine the reserves in the professional readiness of teachers for dealing with specific problem situations in relation to education in elementary schools, as well as outside school. (Skopalová \& Janiš, 2017; Kolaříková, Petrová, \& Urbanovská, 2017). 


\section{Research objectives and methodology}

Research objective. The objective of the study, the results of which are presented in this paper, was to elicit relevant facts on the current readiness of elementary school teachers in the field of risk behavior and its prevention in the Moravian-Silesian Region, as perceived by the teachers themselves. In particular, the objective was to collect and analyze opinions of a selected sample of teachers on the occurrence of risk behavior manifestations at their schools, on preventive activities in the field of risk behavior at school, on the possibilities of addressing the cases of problematic behavior within the school environment, and on the self-reflection of the level of one's own competences to cope with the everyday school reality.

Individual objectives. The study provides a deeper analysis of the individual results. The individual objective was to uncover the structure of relations between variables, to examine the relations between the participants' statements and demographic factors.

Research questions. Several research questions were formulated in accordance with the individual objective with respect to the character of examination (the effort to map and analyze the situation in schools).

1. What is the relation between the subjective perception of effectiveness of one's own educational activity and the participants' involvement in various training programs focusing on the prevention of students' risk behavior? Is the effectiveness of the participants' educational activity, as perceived by them, positively influenced by their overall personal involvement in the area of preventive activities, including participation in various training programs focusing on the prevention of students' risk behavior?

2. What variables are related to the application of effective educational measures? Do the teachers who use effective educational and preventive measures also have adequate knowledge in the field of specific manifestations of risk behavior, or do the teachers who are successful in their educational activity have a sufficient level of personal prerequisites, rather than the knowledge of the specific manifestations, to intuitively resolve the undesirable students' behavior in a correct way?

3. What role do the demographic factors of gender, age, work experience and function held by the study participants who are teachers play in the studied context?

4. What is the share of personal satisfaction from one's own work in the study group of teachers and how is that conditioned?

5. What does the occurrence of the subjective perception of low respect by students relate to?

Properties of the research sample. The research group included a total of 302 teachers from 12 elementary schools (ES) and grammar schools with an extended study program. The schools had been selected on the basis of willingness to participate in the study (only 12 schools out of 52 schools we approached were willing to cooperate). As it was an available selection, the conclusions of the study only apply to the research group. The examined group included 45 men (i.e. $14.9 \%$ ) and 254 women (i.e. $84.1 \%$ ), out of 
which 92 teachers (30.4\%) were at the age of 40 and below, 193 teachers $(63.9 \%)$ were at the age of $41-60$, and 15 teachers (5\%) were at the age of 60 and above. The largest group included teachers with professional experience over 21 years (162 teachers, i.e. $54.6 \%)$. With regard to the type of the school, 125 participants $(41.4 \%)$ worked at the first level of elementary school, 148 participants (49.0\%) worked at the second level of elementary school, and 26 participants worked at both levels (8.6\%).

Research method. To fulfill the set objective, we chose a quantitative research approach and the method of a questionnaire survey. For its purpose, we created our own research instrument, an anonymous questionnaire of our own design. The subjectivity of answers acquired through the questionnaire survey did not represent any risks in our study but it corresponded with our intention: to elicit information on the subjective assessment of the teachers' own readiness to recognize and deal with problematic situations and to participate in the primary prevention of risk behavior.

The selection and formulation of the questionnaire items was based on the research objective, on the requirements and formulations of methodological recommendations of the Ministry of Education, Youth and Sports in the field of primary prevention, and on the Standards of Professional Qualification of the Providers of Programs on the Primary Prevention of Risk Behavior. The questionnaire was consulted by the entire team and corresponding experts who provided their comments during its elaboration (the school prevention coordinator in the Moravian-Silesian Region and the head of the center for alcohol and other addictions).

The questionnaire is divided into three sections. The first section contains questions that elicit demographic data. The second, central part consists of 46 scalable items of the Likert type with the option to express one's attitude to the presented statements on a four-degree scale (definitely yes, rather yes, rather no, definitely no). The last section includes 7 open questions that request to provide free answers.

The data obtained by the questionnaire survey were organized in a matrix and then they were statistically processed using the calculation of relative frequencies, Pearson's correlation coefficient and factor analysis.

Out of the data obtained, only the part prepared by the authors of the article is presented for the purpose of this paper. Only data from scalable items generated on the basis of a factor analysis are included in the following text.

\section{Description and interpretation of collected data}

\section{Factor analysis}

A factor analysis had to be performed first in order to seek answers to the formulated research questions. The collected data were subjected to a factor analysis with a Varimax rotation, with a selected factor load of 0.39 . The factor analysis created four factors with the following running titles:

- F1 - Teachers' preventive activity - includes 10 items that include program participation, cooperation with school methodological prevention and with the 
educational and psychological counseling center, and it describes the involvement, engagement and cooperation with other colleagues and experts on preventive programs for students.

- F2 - Problems with authority and discipline - includes 7 items - describes negative feelings of the teachers concerning respect from students and parents, and also includes the level (frequency) of dealing with conflicts and disciplinary problems with students.

- F3 - Effective educational and preventive influence - includes 11 items describes the friendly relationship to students and knowledge of effective methods of working with student groups.

- F4 - Teachers' incomplete knowledge of specific manifestations of risk behavior

- includes 4 items - this factor combines items focused on insufficient knowledge and methods of work with student groups in the monitored area.

Tables 1-4 present the results of the factor analysis with a description of items and factor load.

Table 1 Factor 1 - Teachers' preventive activity - Factor analysis results Item (with questionnaire order no.)

9. I actively participate in the implementation of primarily preventive activities for the students...

10. I have had the opportunity and have been present on a preventive program for students.

11. I am always interested in participating in a preventive program for students.

12. I assess the preventive programs for students that I have participated in positively.

13. During my presence in a primary prevention program... I learned useful information.

14. I cooperate with the school prevention methodologist when resolving problems with students.

15. I cooperate with the school educational counselor when resolving problems with students.

16. I cooperate with the school psychologist and the counseling center experts when resolving problems with students.

38. I regularly consult the planning of preventive activities and work with the class with the school prevention methodologist.

41. I usually consult other colleagues who teach in the same classes regarding educational and preventive measures.

Factor loading 
Table 2 Factor 2 - Problems with authority and discipline - Factor analysis results

\begin{tabular}{|l|c|}
\hline Item (with questionnaire order no.) & $\begin{array}{c}\text { Factor } \\
\text { loading }\end{array}$ \\
\hline 6. Some students show no respect to me. & 0.70 \\
\hline 7. We often deal with aggression between students at our school. & 0.45 \\
\hline 26. I often deal with aggressive parents; some even insult me. & 0.41 \\
\hline 28. Some students insult me. & 0.68 \\
\hline $\begin{array}{l}\text { 29. I deal with the lack of discipline of students during lessons on a daily } \\
\text { basis. }\end{array}$ & 0.74 \\
\hline 30. There are conflicts among students. & 0.72 \\
\hline 31. I am often disturbed by noise in the classroom during my lessons. & 0.68 \\
\hline
\end{tabular}

Table 3 Factor 3 - Effective educational and preventive influence - Factor analysis results

\begin{tabular}{|l|c|}
\hline Item (with questionnaire order no.) & $\begin{array}{c}\text { Factor } \\
\text { loading }\end{array}$ \\
\hline 17. I prefer discussion when dealing with problems in the class. & 0.44 \\
\hline 21. As a form teacher, I organize regular class lessons. & 0.47 \\
\hline 23. I use the community circle in the class lessons. & 0.64 \\
\hline $\begin{array}{l}\text { 24. When we visit a cultural event with a preventive intention, I try to have } \\
\text { a discussion with the students afterwards, letting them reflect individually... }\end{array}$ & 0.42 \\
\hline 27. I think that the students trust me, they are not afraid to confide in me. & 0.63 \\
\hline 32. I manage to implement an individual approach to students. & 0.51 \\
\hline 33. Also, I often talk to students about their lives. & 0.63 \\
\hline $\begin{array}{l}\text { 39. I always try to get the students in the right mood with a short informal } \\
\text { conversation, game or a ritual before the lesson. }\end{array}$ & 0.58 \\
\hline $\begin{array}{l}\text { 40. In the classroom, I use a specific form of agreement on mutual behavior } \\
\text { (verbal or written) and I refer to it actively whenever needed. }\end{array}$ & 0.54 \\
\hline $\begin{array}{l}\text { 42. I focus more on a positive feedback (praise) than on punishment } \\
\text { and reprimands for undesirable behavior. }\end{array}$ & 0.52 \\
\hline \begin{tabular}{l} 
43. I consider it proper to address all the students in the same way. \\
\hline
\end{tabular} & 0.42 \\
\hline
\end{tabular}


Table 4 Factor 4 - Teacher's incomplete knowledge of specific manifestations of risk behavior - Factor analysis results

\begin{tabular}{|l|c|}
\hline Item (with questionnaire order no.) & $\begin{array}{c}\text { Factor } \\
\text { loading }\end{array}$ \\
\hline 22. I only use the class lessons for organizational matters. & 0.43 \\
\hline $\begin{array}{l}\text { 34. I believe that single-time aggression between students is also one of the } \\
\text { basic signs of bullying. }\end{array}$ & 0.50 \\
\hline $\begin{array}{l}\text { 36. In my opinion, having a small amount of marijuana for the user's own } \\
\text { needs (according to the Czech Criminal Code) is a criminal offense. }\end{array}$ & 0.45 \\
\hline $\begin{array}{l}\text { 37. I believe that if the police find illegal drugs on someone, they will } \\
\text { confiscate the drug along with the things used for its application (e.g. } \\
\text { syringe). }\end{array}$ & 0.59 \\
\hline
\end{tabular}

We analyzed the internal consistence of factors (using the Cronbach's alpha coefficient) and determined their mutual correlations. The formulation of the factors helped us assess other criteria and relations between the individual groups of participants.

\section{Correlation between variables and discussion on the results}

The inter-correlations of factors (see table 5) helped us answer the questions set above. The strongest relation, that is a medium-strong statistical relation, was determined between factors $\mathbf{F 1}$ and $\mathbf{F 3}$, which means that the factor of preventive activity is in a significant mutual relation with the subjectively perceived effective educational and preventive influence. This fact brings a positive answer to the first research question. Specifically, it means a connection between the subjectively perceived effectiveness of the teacher's own educational activity and the activity in the field of prevention, willingness to cooperate with colleagues and experts, and the effort to behave supportively, emphatically, consistently and justly. A significant relation was also found between factors F3 and F4 and it is expressed in the answer to the second research question. This positive correlation indicates a rather surprising relation when teachers use effective educational and preventive measures, while manifesting incomplete knowledge in the field of specific manifestations of risk behavior. In the context of this relation, the question is whether teachers who are successful in their educational influence have a sufficient level of personality prerequisites to address undesirable manifestations of students in an intuitively correct manner, or they are only more critical of their professional readiness. Factor $\mathbf{F} 2$ does not correlate with any other factor. 
Table 5 Inter-correlation of factors

\begin{tabular}{|l|c|c|c|c|}
\hline Factor & F1 & F2 & F3 & F4 \\
\hline F1 Teachers' preventive activity & - & 0.04 & $0.40^{\star \star \star}$ & 0.11 \\
\hline F2 Problems with authority and discipline & 0.04 & - & -0.01 & 0.12 \\
\hline $\begin{array}{l}\text { F3 Effective educational and preventive } \\
\text { influence }\end{array}$ & $0.40^{\star \star \star}$ & -0.01 & - & $0.33^{\star \star \star}$ \\
\hline $\begin{array}{l}\text { F4 Teacher's incomplete knowledge of } \\
\text { specific manifestations of risk behavior }\end{array}$ & 0.11 & 0.12 & $0.33^{\star \star \star}$ & - \\
\hline
\end{tabular}

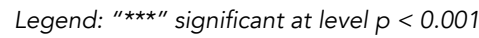

The answers to the remaining research questions are provided by the following values determined.

Correlation of factors and demographic variables (third research question). When monitoring the correlations of the individual factors with other variables, such as gender, age, duration of work experience, function and so on, no statistically significant relation was found in. We can only notice minor, non-random differences when we accept a lower (almost negligible) effect related to the lower values of the correlation coefficient (when we choose the lowest relevant value $r>0.10$ ). For example, women and younger teachers stated a higher involvement in the field of preventive activities than men and older teachers. As the age and duration of work experience increase, the subjective feeling of difficulties with discipline, aggression and lack of respect from the students also increases.

Considering the mentioned low values of statistical significance of the individual relations, the elicited relations need to be approached with the knowledge that they are implied tendencies that provide an approximate evidential value and their interpretation is only an inspirational contemplation.

Correlation of demographic variables to the individual items. When examining the correlations of demographic variables to the individual items, some interesting facts and significant differences, presented below, were ascertained.

In most items, no statistically significant difference was found in the answers of men and women. The following findings represent an exception: (a) women use agreement with students on adherence to the rules and talk to students about their lives more often than men; (b) younger teachers cooperate on preventive activities with a prevention methodologist and a school psychologist more often than their older colleague.

More significant differences were ascertained with regard to the duration of work experience. Teachers with a longer work experience are more likely to feel that they have issues with being respected as an authority, lower discipline and respect to their person, and they complain about noise in the classroom. The following questions emerged: Is the respect by the students really smaller or do older teachers require a higher level of respect? Are older teachers more sensitive to the students' behavior and cannot tolerate a noisy atmosphere in the classroom as much? Also, the level of cooperation on preventive 
activities together with a school methodologist, school psychologist, the educational and psychological counseling center and so on decreases with the increasing duration of work experience. Once again, we could discuss the causality of this phenomenon: Are older colleagues more experienced and do not need consultations? Or does fatigue and unwillingness to cooperate play a role here?

Correlation between individual items. The correlations found between the individual items also indicate some important facts. There were relations found between whether or not the participant feels appreciated for his or her educational work, together with the opportunity to use his or her ideas to improve work, and also, whether or not the principal is interested in what happens in the individual classrooms.

Other connections were related to the satisfaction of the teachers with their work. The teachers who are satisfied by their educational work (93.4\%) are more likely to state that they experience appreciation of their activity, that they can use their own ideas, and that the principals are interested in what happens in the classrooms. Also, they are less likely to have issues with discipline, aggression and conflicts among students in the classroom, they actively participate in preventive activities for their classroom, use the community circle in their homeroom periods, and approach students individually. They are also more likely to consult educational and preventive measures with their colleagues. It means that satisfaction with one's work in the case of our participants is related to the recognition and support from the principals, implementation of preventive activities and fewer difficulties with discipline. That is where we see the core of the answer to the fourth research question.

We found more frequent correlations in the item describing the level of respect and discipline. Teachers who feel a lower respect from students (approx. 27\% participants) are more likely to show low involvement in the preventive activities for students, dissatisfaction with their work activity and a feeling of low respect, they are more likely to state problems with parents, daily discipline problems or aggression in the classroom. They are less likely to apply an individual approach and to approach all the students in the same way, they do not orientate as much on positive motivation and praise, and prefer punishment and reprimand. With respect to this and the aforesaid findings, we can state, in relation to the last, fifth research question, that the perception of low respect on the part of students and the higher occurrence of problems with discipline are related to the work experience of our participants, their lower involvement in preventive activities, and a less frequently applied individual and positive approach to students.

\section{Concluding summary}

The presented questionnaire survey has brought numerous positive findings. Teachers in our research group are willing to monitor current events in education, to communicate with students and to create a safe environment in school. Teachers are mostly satisfied with their work, they feel appreciated, their principals are interested in what happens in the classrooms, and they can use their own ideas. 
Most teachers are willing to cooperate with other colleagues, with the prevention methodologist, with school counselors, educational and psychological counseling centers and other experts. They consider the implemented preventive programs to be beneficial, even for themselves. Other positive findings include the teachers' effort to incorporate preventive activities into their own lessons. Most teachers prefer a discussion with students in the classroom when there is a problem. Discussion is often used within the homeroom period and after preventive events. The teachers consider the extracurricular offer in their schools to be sufficient and they appreciate its meaning with regard to primary prevention.

At the level of subjective assessment of the relationships with students and parents, there were also positive results. A high percentage of teachers believe that students trust them (over $90 \%$ ), most teachers speak with students about their reality, and they apply an individual as well as equal approach to all students. Most teachers mostly strive to provide positive feedback to their students, to create a positive atmosphere in the classroom, and to apply the agreed rules. The feeling of low respect from the students and the lack of discipline are more frequent in teachers who do not apply the aforesaid approaches as much.

The teacher's perceptiveness to the children's problems and a wide range of social and pedagogical competences are important both in the process of resolving negative consequences and in the process of primary prevention of risk behavior. Most of the teachers have encountered risk behaviors and they strive to address such situations effectively, with the assistance of consultants, and they develop activities to prevent such behavior. The responses to the set research questions showed a close positive relation between the perceived effectiveness of one's own educational activity and the overall personal involvement in the field of preventive activities, a relation between one's own personal satisfaction with work and the recognition and support of principals, implementation of preventive activities and fewer disciplinary problems, and finally, a relation between the perception of low respect and occurrence of disciplinary problems and the work experience, participation in preventive activities and less frequent application of an individual and positive approach to students.

Even though the presented results relate to a study that took place in 2017, we can assume that similar relations would be also found at present. However, it would have to be verified by a new research study. The conclusions of this survey, however, can only be applied to the examined group, formed by teachers in schools that were willing to participate in the study, which could influence the results to some extent. In spite of these limitations, the outcomes can be considered relevant and inspirational for the professional and teaching public. 


\section{References}

Csémy, L., Hrachovinová, T., Čáp, P., \& Starostová, O. (2014). Agresivní chování dospívajících: prevalence a analýza vlivu faktorů z oblasti rodiny, vrstevnických vztahů a školy [Aggressive behavior of adolescents: prevalence and analysis of the role of family, peer and school-related factors]. Československá psychologie, 58(3), 242-253.

Haggerty, R. J., \& Garmezy, N. (1996). Stress, risk and resilience in children and adolescents: processes, mechanisms and interventions. Cambridge: Cambridge University Press.

Jedlička, R. et al. (2015). Poruchy socializace u dětí a dospívajících: prevence životních selhání a krizová intervence. Praha: Grada.

Jennings, P. A., Brown, J. L., Frank, J. L., Doyle, S., Oh, Y., Davis, R., ... Greenberg, M. T. (2017). Impacts of the CARE for Teachers program on teachers' social and emotional competence and classroom interactions. Journal of Educational Psychology, 109(7), 1010-1028. doi: 10.1037/edu0000187

Kolařiková, M., Petrová, A., \& Urbanovská, E. (2017). Profesní pripravenost učitelů základních škol $v$ oblasti řešení rizikového chování a možnosti jeho prevence v Moravskoslezském kraji. II. Psychologické aspekty. Opava: Slezská univerzita v Opavě [Silesian University in Opava].

Kraus, B. et al. (2001). Člověk - prostředí - výchova: k otázkám sociální pedagogiky. Brno: Paido.

Lopes, J. et al. (2017). Teacher's Classroom Management Behavior and Students' Classroom Misbehavior: A Study with $5^{\text {th }}$ through $9^{\text {th }}$-Grade Students. Electronic Journal of Research in Educational Psychology, 15(3), 467-490. doi: 10.14204/ejrep.43.17075

Miovský, M. et al. (2010). Primární prevence rizikového chování ve školství. Praha: Sdružení SCAN.

Rucinski, C. L., Brown, J. L., \& Downer, J. T. (2018). Teacher-child relationships, classroom climate, and children's social-emotional and academic development. Journal of Educational Psychology, 110(7), 992-1004. doi: 10.1037/edu0000240

Sádovská, A., \& Kusý, P. (2019). Vztáah interakčného štýlu učitel'a a seba-vnímanej životnej zmysluplnosti v kontexte prosociálnosti [Relation between teacher interaction style and self-perceived meaning in life in the context of prosociality]. Československá psychologie, 63(4), 476-490. 
Skopalová, J., \& Janiš, K. (2017). Profesní připravenost učitelů základních škol v oblasti řešení rizikového chování a možnosti jeho prevence $v$ Moravskoslezském kraji. I. Pedagogické aspekty. Opava: Slezská univerzita v Opavě [Silesian University in Opava].

Špatenková, N. et al. (2017). Krize a krizová intervence. Praha: Grada.

Valenta, J. (2013). Didaktika osobnostní a sociální výchovy. Praha: Grada.

Vágnerová, M. (2014). Současná psychopatologie pro pomáhající profese. Praha: Portál.

Werner, E. E. (1990). Protective factors and individual resilience. In S. J. Meisels, \& J. P. Shonkoff (Eds.), Handbook of early childhood intervention (pp. 97-116). New York: Cambridge University Press.

Zimmermann, P. (2002). Von Bindungserfahrungen zur individuellen Emotionsregulation: das entwicklungspsychopathologische konzept der Bindungstheorie. In A. Buchheim, \& H. Kächele, Klinische Bindungsforschung (pp. 147-161). Stuttgart: Schattauer.

\section{Authors}

doc. PhDr. Eva Urbanovská, Ph.D.

Faculty of Humanities, University of Žilina

Department of Pedagogical Studies

Univerzitná 8215/1, 01026 Žilina, Slovak Republic

evaurb@volny.cz

doc. PhDr. Alena Petrová, Ph.D.

Faculty of Education, University of Ostrava

Department of Educational and School Psychology

Fráni Šrámka 3, 70900 Ostrava, Czech Republic

alena.petrova@osu.cz 